\title{
Risks of Long-Acting Beta-Agonist in Asthma-Perceived or Real?
}

\section{Li-Cher Loh*}

Lung Research, Penang Medical College, Penang, Malaysia

The concern about safety of long-acting $\beta_{2}$-agonist (LABA) in asthma is not new and is a spill-over from that of short-acting $\beta_{2}$ agonist. The consensus, and not conclusion, by regulatory authorities especially FDA of US, requires that LABA should be prescribed together with a regular asthma controlled medication such as inhaled corticosteroid (ICS). FDA, in their latest safety warning of 2010 [1], further recommends that the use of LABA should be limited whenever asthma control can be achieved on regular ICS alone.

However this remains as consensus because of ongoing debate as to the true nature of LABA risk in asthma. Following the trend of debate since approval of salmeterol by FDA in 1994, studies like Serevent Nationwide Surveillance study from UK [2] and Salmeterol Multicentre Asthma Research Trial (SMART) from US [3], favored the understanding that LABA increases asthma-related death. However the studies especially SMART are heavily criticized including its problematic recruitment and misclassification of death [4]. Several meta-analyses that were conducted based on combined clinical trial data did not reach satisfactory conclusion either [5-7]. One key argument against LABA's risk of death is that the observed incidence of such is already small and that they are not necessarily attributable to LABA use [7]. What is clear is simply the surprising lack of safety data on LABA from properly powered prospective studies to date. Such studies should include both adult and children, and have appropriate comparators. This lack has dismayed many including the regulatory authorities.

It is noteworthy that the clinical benefit of LABA in asthma remains strong and well tested over a decade now. It would seem illogical to remove a therapy that has such proven record. Its efficacies on symptom relieve and lung function improvement in persistent asthmatics is solid enough to be recommended as the standard first line add-on therapy to regular ICS. The argument that LABA masks underlying airway inflammation seems unfounded when it is combined with ICS. This is because combined ICS/LABA treatment further reduces frequency and severity of asthma exacerbation, and not the reverse $[8,9]$. This approach has become the normalcy in most asthma guidelines today and has revolutionized the landscape of asthma management beyond that of theophylline and oral corticosteroids that were historically the add-on for poorly controlled asthmatics on regular ICS alone. LABA as add-on appears the most effective among all other add-ons including leukotriene receptor antagonist [10]. For COPD, LABA is also increasingly shown to be a primary therapy that is safe [11]. This is relevant for older patients with chronic airways diseases where the delineation between asthma and COPD is not always clear. In fact, it has a practical importance that combined ICS and LABA treatment is now an effective therapy for both asthma and COPD of moderateto-severe severity. As such, from the treatment perspective for busy practicing clinicians, it is not overtly important to distinguish whether one has asthma or COPD or both in certain patients.

Given the current knowledge of the pros and cons in the debate of LABA safety, it is no surprise that any decision on LABA safety to date remains a consensus and arguable and that it is still unclear whether its risks are real or perceived. The regulatory requirement for the black box safety labeling to warn public and physicians of the possible risks is prudent and justifiable. Latest FDA recommendation to restrict the use of LABA should not be construed in a negative manner given that the jury is still out on the absolute safety of LABA prescribed for a disease as prevalent as asthma.

\section{References}

1. Chowdhury BA, Dal Pan G (2010) The FDA and Vafe Xse of Ong-Dcting EetaDgonists in the Treatment of Asthma. N Engl J Med 362: 1169-1171.

2. Castle W, Fuller R, Hall J, Palmer J (1993) Serevent nationwide surveillance study: comparison of salmeterol with salbutamol in asthmatic patients who require regular bronchodilator treatment. BMJ 306: 1034-1037.

3. Nelson HS, Weiss ST, Bleecker ER, Yancey SW, Dorinsky PM, et al. (2006) The 6 almeterol 0 ulticenter \$sthma Research Trial: a comparison of usual pharmacotherapy for asthma or usual pharmacotherapy plus salmeterol. Chest 129: 15-26.

4. O’Byrne PM, Adelroth $\mathrm{E}$ (2006) Beta 2 déjà vu. Chest 129: 3-5.

5. Martinez FD (2005) Safety of long-acting beta-agonists-an urgent need to clear the air. N Engl J Med 353: 2637-2639.

6. Kramer JM (2009) Balancing the benefits and risks of inhaled long-acting betaagonists- the influence of values. N Engl J Med 360: 1592-1595.

7. Drazen JM, O'Byrne PM (2009) Risks of long-acting beta-agonists in achieving asthma control. N Eng J Med 360: 1671-1672.

8. O'Byrne PM, Bisgaard H, Godard PP, Pistolesi M, Palmqvist M, et al. (2005) Budesonide/formoterol combination therapy as both maintenance and reliever medication in asthma. Am J Respir Crit Care Med 171: 129-136.

9. Bateman ED, Boushey HA, Bousquet J, Busse WW, Clark TJ, et al. (2004) Can guideline-defined asthma control be achieved? The Gaining Optimal Asthma Control study. Am J Respir Crit Care Med 170: 836-844.

10. Nelson HS (2001) Combination therapy of bronchial asthma. Allergy Asthma Proc 22: 217-220.

11. Tashkin DP, Fabbri LM (2010) Long-acting beta-agonists in the management of chronic obstructive pulmonary disease: current and future agents. Respir Res 11: 149.
*Corresponding author: Dr. Li-Cher Loh, Lung Research, Penang Medical College, JalanSepoy Lines, Penang 10450, Malaysia, Tel: (+604) 226 3459; Fax: (+604) 227 6529; E-mail: richard_loh@pmc.edu.my

Received March 21, 2012; Accepted March 23, 2012; Published March 25, 2012

Citation: Loh LC (2012) Risks of Long-Acting Beta-Agonist in Asthma-Perceived or Real?. J Pulmonar Respirat Med 2:e115. doi:10.4172/2161-105X.1000e115

Copyright: (c) 2012 Loh LC. This is an open-access article distributed under the terms of the Creative Commons Attribution License, which permits unrestricted use, distribution, and reproduction in any medium, provided the original author and source are credited. 